\title{
VARIABILITY OF MICROSATELLITES IN SHEEP BREEDS RACED IN RUSSIA
}

\section{T.E. DENISKOVA ${ }^{1}$, M.I. SELIONOVA², E.A. GLADYR'1, A.V. DOTSEV1, G.T. BOBRYSHOVA ${ }^{2}$, O.V. KOSTYUNINA ${ }^{1}$, G. BREM ${ }^{3}$, N.A. ZINOVIEVA ${ }^{1}$}

\author{
${ }^{1}$ L.K. Ernst All-Russian Research Institute of Animal Husbandry, Federal Agency of Scientific Organizations, pos. \\ Dubrovitsy, Podolsk District, Moscow Province, 142132 Russia, e-mail tandeniss@rambler.ru; \\ ${ }_{2}^{2}$ All-Russian Research Institute of Sheep and Goat Breeding, Federal Agency of Scientific Organizations, 15, per. Zo- \\ otechnicheskii, Stavropol, 355017 Russia; \\ ${ }^{3}$ Institut für Tierzucht und Genetik, University of Veterinary Medicine (VMU), Veterinärplatz, A-1210, Vienna, Aus- \\ tria, e-mail gottfried.brem@agrobiogen.de \\ Acknowledgements: \\ We thank Dr R.V. Ivanov (Yakut Research Institute of Agriculture) for assistance in collecting samples \\ Supported by Russian Science Foundation (project № 14-36-00039) \\ Received September 26, 2016
}

\section{Abstract}

At the current stage of biological development is impossible to establish conservation programs and to monitor genetic resources of sheep without a preliminary study by DNA markers. The Russian sheep breeding is represented by wide variety of breeds, including all productivity and wool types. However, until recently only some sheep breeds, which belong to the same breeding zone or productivity type, were investigated by DNA markers including microsatellites. We studied 25 Russian sheep breeds $(n=751)$, including fine-fleeced - Dagestan Mountain (DAG), Grozny (GRZ), Kulunda (KUL), Manych Merino (MNM), Salskaya (SAL), Stavropol (STA), Soviet Merino (SVM), Volgograd (VOL), Baikal's fine-fleeced (ZBL); semi fine-fleeced - Altay Mountain (ALT), Kuibyshev (KUI), North Caucasian (NC), Russian long-haired (RLH), Tsigai (TSIG); coarsewooled - Andean (AND), Buubey (BUB), Edilbai (EDL), Karachaev (KAR), Kuchugur (KCH), Kalmyk (KLM), Karakul (KRK), Lezgin (LEZ), Romanov (ROM), Tushin (TSH), Tuvan short fat-tailed (TUV). The research was conducted using 11 microsatellite loci (OarCP49, INRA063, HSC, OarAE129, MAF214, OarFCB11, INRA005, SPS113, INRA23, MAF65 и McM527). The data were processed using GenAIEx 6.5 and PAST software. In general, the studied breeds were characterized by moderately high allelic diversity. The average number of alleles per locus is varied from $7.20 \pm 0.98$ in KUL and $10.30 \pm 0.99$ in TSIG. The values of $\mathrm{Na} 10.0$ were found in TSIG, TUV, BUB and KRK, values of $\mathrm{Na} 8.0$ were identified in KUL, RLH and SVM. The effective allele number was the highest in the KRK and TUV ( Ne 5.7) and the minimum was detected in KCH, ALT, $\mathrm{RLH}$ and $\mathrm{NC}(\mathrm{Ne} 4.3)$. The level of the observed heterozygosity in 21 of the 25 studied breeds ranged from $0.489 \pm 0.095$ in TUV to $0.651 \pm 0.050$ in ROM and $0.651 \pm 0.060$ in SVM, and four other breeds (BUB, TSIG, ZBL and TUV) it varied from $0.798 \pm 0.023$ in BUB up $0.977 \pm 0.017$ in TUV. There was a substantial deficit of heterozygotes in 21 of the 25 studied breeds $\left(\mathrm{F}_{\mathrm{IS}}\right.$ values ranged from 0.13 in ROM to 0.36 in KAR and SAL), in the other four (BUB, TSIG, ZBL and TUV) an excess of heterozygotes $\left(F_{I S}\right.$ values ranged from -0.04 to -0.22$)$ was detected. The analysis of molecular variance (AMOVA) showed that $5.02 \%$ of genetic variation is composed of differences among breeds and $94.98 \%$ is explained by within breeds' component. Analysis of the structure of the UMPGA phylogenetic tree, based on the matrix of pairwise genetic distances by M. Nei (1972), showed that the nature of the identified relationships is mainly related with the wool type, productivity type and breeding region. Thus, the identified polymorphism of eleven microsatellite loci is quite powerful for differentiating sheep of various breeds. For a better understanding population structure and obtaining new information on the genetic diversity at the genomic level the application of DNA microarrays, based on the multiple SNPs-markers, is required.

Keywords: sheep breeds, microsatellites, genetic diversity

Thanks to advancing DNA-based technology, various genetic markers have been detected and applied, including microsatellites, which became an important source of information about the current status of animal genetic resources [1, 2]. Choosing microsatellites as genetic markers is determined by their 
unique features, such as the widespread and uniform distribution in the genome, allelic diversity, great informative value, codominant Mendelian-type inheritance, high reproducibility, and ease of analysis automation [3-5]. In the global and domestic practice of sheep rearing, microsatellite analysis is used to assess the genetic diversity of breeds and study phylogenetic relationships between them [6-8], proof of origin [9] and pedigree of animals [10], to investigate the population structure and genetic drift [11, 12], and establish the level of inbreeding in specific groups and herds [13].

Currently, high-performance genotyping methods are increasingly used, such as genome-wide SNP (single nucleotide polymorphism), scanning using DNA microarrays with different densities [14-17] and genotyping-by-sequencing (GBS) [18]. Despite this, microsatellites remain relevant as highly informative DNA markers in conducting population genetic studies [5]. A microsatellitebased analysis is still an indispensable tool for the routine animal testing on the origin authenticity and the breed. This is primarily due to the fact that the panels for origin diagnostics based on highly informative SNP markers are rather expensive, and blood groups are much inferior to the microsatellites in the testing accuracy [19].

In Russia, there are 37 sheep breeds, including 13 fine-fleeced, 10 semifine-fleeced, 12 coarse-wool and 2 medium-wool breeds [20]. They are also represented by all known types based on productivity (wool, mutton-wool, wool and meat, fur, fat-tailed, mutton-wool and dairy, hair and meat). This diversity is due to the peculiarities of climate, feed and social factors in the regions where the breeds were developed.

In recent years, genetic studies have been performed on some Russian breeds of sheep using the microsatellite markers [21-23]. Within the framework of the genetic diversity study program and the establishment of the population structure of sheep breeds in North Eurasia, the Russian breeds were compared with breeds from Norway, Denmark, Sweden and Estonia [24]. For the genetic classification of semifine-fleeced breeds, the Kuibyshev, Russian long-haired and North Caucasian mutton-wool sheep breeds were involved [25]. However, until now genetic studies of sheep based on the microsatellite markers in Russia have involved only several breed groups, combined by the productivity type or a breeding region.

In this paper, we first studied and compared 25 Russian sheep breeds representing all known types by their microsatellite markers. In general, polymorphism in 11 microsatellite loci was quite informative for the interbreed differentiation. Our findings most completely reflect the state of the allele pool and genetic diversity of most of the major sheep breeds, commonly spread in Russia.

The purpose of the research was the study of variability of microsatellites, the assessment of diversity and degree of genetic differentiation among different sheep breeds, raised in Russia.

Technique. Tissue samples were taken from sheep of 25 Russian breeds, such as fine-fleece, semifine-fleece, coarse-wool, with different types of meat, wool and dairy productivity $(n=751)$.

To isolate the DNA the Nexttec columns (Nexttec Biotechnologie $\mathrm{GmbH}$, Germany) were used, as well as the DNA Extran test kit (CJSC Syntol, Russia) and the extraction method using sodium perchlorate [26]. For the genetic research, we selected 11 microsatellite loci grouped into two multiplex panels including the following loci: OarCP49, INRA063, HSC, OarAE129, MAF214, OarFCB11, INRA005, and SPS113, INRA23, MAF65 and McM527 loci. The reactions were performed in a final volume of $10 \mu \mathrm{l}$ in the PCR buffer containing $2 \mathrm{mM}$ dNTPs, $1.0 \mathrm{mM}$ of $\mathrm{MgCl}_{2}, 0.5 \mathrm{mM}$ of the primer mixture, 1 unit of 
Taq-polymerase (Dialat Ltd., Russia), and 50-100 ng of genomic DNA. The composition of the PCR buffer was as follows: $16.6 \mathrm{mM}\left(\mathrm{NH}_{4}\right)_{2} \mathrm{SO}_{4}, 67.7 \mathrm{mM}$ of Tris- $\mathrm{HCl}(\mathrm{pH}=8.8), 0.1 \mathrm{vol}$ of Tween 20. After the initial denaturation $\left(95{ }^{\circ} \mathrm{C}, 4 \mathrm{~min}\right.$ ) we performed 41 (Panel 1) and 35 (Panel 2) amplification cycles in the following temperature-time regime: $95{ }^{\circ} \mathrm{C}$, $20 \mathrm{sec} ; 63^{\circ} \mathrm{C}$ (Panel 1) and $55{ }^{\circ} \mathrm{C}$ (Panel 2), $30 \mathrm{sec} ; 72{ }^{\circ} \mathrm{C}, 1 \mathrm{~min}$. Fragments were examined using the ABI3130xl genetic analyzer (Applied Biosystems, USA) and GeneMapper 4 software (Applied Biosystems, USA).

The GenAIEx 6.5 software [27] was used to calculate the following statistical parameters: mean number of alleles per locus $(\mathrm{Na})$, the effective number of alleles $(\mathrm{Ne})$, the number of informative alleles or alleles with a frequency of $>5 \%(\mathrm{Na} 5 \%)$, the expected $\left(\mathrm{H}_{\mathrm{e}}\right)$ and observed $\left(\mathrm{H}_{\mathrm{o}}\right)$ heterozygosity, and inbreeding coefficient $\left(\mathrm{F}_{\mathrm{IS}}\right)$. The degree of genetic differentiation of breeds was assessed by the $\mathrm{F}_{\mathrm{ST}}$ parameter [28] and genetic distances by $\mathrm{M}$. Nei $\left(\mathrm{D}_{\mathrm{N}}\right)$ [29] for paired comparison. The $\mathrm{F}_{\mathrm{ST}}$ values were visualized by analyzing the principal coordinates (Principal Coordinates Analysis, PCoA) using GenAIEx 6.5 software. Based on the genetic distance matrix by M. Nei [29] in the PAST software [30], a phylogenetic tree was built by the unweighted pair-group method using arithmetic averages (UPGMA).

Results. Table 1 provides a summary of sheep population involved in the study.

1. The characteristics of 25 breeds of sheep (Ovis aries), most common in Russia and assessed based on 11 microsatellite loci $(n=751)$

\begin{tabular}{|c|c|c|c|}
\hline Breed & Code & $n$ & Region \\
\hline \multicolumn{4}{|c|}{ Fine-fleece breeds } \\
\hline \multicolumn{4}{|r|}{ Wool } \\
\hline Grozny & GRZ & 30 & Republic of Kalmykia \\
\hline Stavropol & STA & 32 & Stavropol Krai, Kalmykia \\
\hline Manych Merino & MNM & 30 & Stavropol Krai \\
\hline Soviet Merino & SVM & 23 & Stavropol Krai \\
\hline Salskaya & SAL & & Rostov Province \\
\hline \multicolumn{4}{|c|}{ Mutton-Wool } \\
\hline Volgograd & VLG & 30 & Volgograd Province \\
\hline Dagestan Mountain & DAG & & Republic of Dagestan \\
\hline \multicolumn{4}{|c|}{ Wool and meat } \\
\hline Transbaikalian fine-fleece & ZBL & 30 & Republic of Sakha (Yakutia) \\
\hline Kulunda & KUL & 30 & Altai Krai \\
\hline \multicolumn{4}{|c|}{$\begin{array}{c}\text { Se mifin e-fle e c e b ree d s } \\
\text { Mutton-Wool }\end{array}$} \\
\hline Russian long-haired & RLH & 30 & Voronezh Province \\
\hline Kuibyshev & KUI & 30 & Samara Province \\
\hline North Caucasian Mutton-Wool & $\mathrm{NC}$ & & Stavropol Krai \\
\hline \multicolumn{4}{|c|}{ Wool and meat } \\
\hline Tsigai & TSIG & 30 & Saratov Province, Rostov Province \\
\hline Altay Mountain semifine-fleece & ALT & & Altai Krai \\
\hline \multicolumn{4}{|c|}{$\begin{array}{c}\mathrm{Co} \text { a r s e }-\mathrm{w} \text { o o } 1 \text { b r e e d s } \\
\text { Hair and meat }\end{array}$} \\
\hline Romanov & ROM & & $\begin{array}{l}\text { Yaroslavl Province, Ryazan Province, Moscow Province. } \\
\text {-bearing }\end{array}$ \\
\hline Karakul & KRK & & $\begin{array}{l}\text { Republic of Kalmykia, Astrakhan Province } \\
\text { t-tailed }\end{array}$ \\
\hline Edilbai & EDL & 30 & Volgograd Province \\
\hline Kalmyk fat-rumped & KLM & & Republic of Kalmykia \\
\hline \multicolumn{4}{|c|}{ Mutton-Wool } \\
\hline Buubey & BUB & 30 & Republic of Sakha (Yakutia) \\
\hline Tuvan short fat-tailed & TUV & 30 & Republic of Tyva \\
\hline Kuchugur & $\mathrm{KCH}$ & 34 & Voronezh Province \\
\hline \multicolumn{4}{|c|}{ Dual-purpose and dairy } \\
\hline Karachaev & KAR & 30 & Karachay-Cherkessia \\
\hline Lezgin & LEZ & 30 & Republic of Dagestan \\
\hline Andean & AND & 30 & Republic of Dagestan \\
\hline Tushin & TSH & 30 & Republic of Dagestan \\
\hline
\end{tabular}

The average number of alleles per locus ranged from $7.20 \pm 0.98$ in KUL 
to $10.30 \pm 0.99$ in TSIG (Table 2). The highest values of this parameter were characteristic of four breeds (TSIG, TUV, BUB, KRK with Na 10.0), the lowest - of three breeds (KUL, RLH, SVM with Na 8.0). The effective number of alleles was highest in KRK and TUV breeds (Ne 5.7), and lowest - in $\mathrm{KCH}$, ALT, RLH and NC breeds ( $\mathrm{Ne} \mathrm{4.3).} \mathrm{The} \mathrm{range} \mathrm{of} \mathrm{variability} \mathrm{in} \mathrm{terms} \mathrm{of} \mathrm{the}$ number of informative alleles per locus $(\mathrm{Na} 5 \%)$ varied from 4.70 in STA to 6.40 in TSIG.

2. The characteristics of the allele pool and genetic diversity parameters in the Russian breeds of sheep (Ovis aries) by 11 microsatellite loci

\begin{tabular}{|c|c|c|c|c|c|c|}
\hline Breed & $\mathrm{Na}$ & $\mathrm{Ne}$ & $\mathrm{Na} 5 \%$ & $\mathrm{H}_{\mathrm{O}}$ & $\mathrm{H}_{\mathrm{e}}$ & $\mathrm{F}_{\text {IS }}$ \\
\hline$\overline{\mathrm{EDL}}$ & $9.30 \pm 1.21$ & $4.66 \pm 0.71$ & $5.30 \pm 0.72$ & $0.557 \pm 0.073$ & $0.730 \pm 0.043$ & $0.27 \pm 0.07$ \\
\hline VLG & $8.90 \pm 1.22$ & $5.08 \pm 0.70$ & $5.80 \pm 0.63$ & $0.525 \pm 0.082$ & $0.751 \pm 0.047$ & $0.33 \pm 0.08$ \\
\hline SAL & $8.50 \pm 0.92$ & $5.05 \pm 0.63$ & $5.90 \pm 0.64$ & $0.512 \pm 0.089$ & $0.764 \pm 0.036$ & $0.36 \pm 0.09$ \\
\hline KAR & $9.20 \pm 1.10$ & $5.25 \pm 0.72$ & $5.70 \pm 0.63$ & $0.516 \pm 0.087$ & $0.764 \pm 0.040$ & $0.36 \pm 0.09$ \\
\hline KLM & $9.50 \pm 0.96$ & $5.07 \pm 0.63$ & $5.90 \pm 0.50$ & $0.577 \pm 0.071$ & $0.771 \pm 0.030$ & $0.27 \pm 0.08$ \\
\hline GRZ & $9.00 \pm 1.14$ & $4.92 \pm 0.62$ & $5.40 \pm 0.67$ & $0.540 \pm 0.089$ & $0.761 \pm 0.033$ & $0.33 \pm 0.09$ \\
\hline DAG & $9.00 \pm 1.07$ & $5.45 \pm 0.82$ & $5.40 \pm 0.86$ & $0.560 \pm 0.079$ & $0.774 \pm 0.032$ & $0.30 \pm 0.08$ \\
\hline TSH & $9.60 \pm 1.13$ & $5.02 \pm 0.79$ & $5.70 \pm 0.60$ & $0.507 \pm 0.081$ & $0.748 \pm 0.042$ & $0.35 \pm 0.08$ \\
\hline AND & $8.70 \pm 0.98$ & $4.80 \pm 0.58$ & $5.40 \pm 0.65$ & $0.550 \pm 0.074$ & $0.757 \pm 0.033$ & $0.29 \pm 0.08$ \\
\hline LEZ & $8.60 \pm 0.72$ & $4.74 \pm 0.74$ & $5.80 \pm 0.71$ & $0.510 \pm 0.070$ & $0.730 \pm 0.044$ & $0.33 \pm 0.06$ \\
\hline ALT & $8.50 \pm 0.99$ & $4.28 \pm 0.70$ & $4.80 \pm 0.61$ & $0.509 \pm 0.084$ & $0.678 \pm 0.065$ & $0.26 \pm 0.09$ \\
\hline KUL & $7.20 \pm 0.98$ & $4.42 \pm 0.72$ & $5.30 \pm 0.70$ & $0.489 \pm 0.095$ & $0.701 \pm 0.053$ & $0.33 \pm 0.12$ \\
\hline KRK & $10.00 \pm 0.91$ & $5.75 \pm 0.86$ & $5.40 \pm 0.76$ & $0.634 \pm 0.047$ & $0.785 \pm 0.033$ & $0.20 \pm 0.04$ \\
\hline KUI & $8.50 \pm 1.06$ & $5.32 \pm 0.80$ & $5.90 \pm 0.69$ & $0.646 \pm 0.052$ & $0.767 \pm 0.036$ & $0.16 \pm 0.05$ \\
\hline $\mathrm{KCH}$ & $9.20 \pm 1.15$ & $4.24 \pm 0.53$ & $4.80 \pm 0.39$ & $0.574 \pm 0.059$ & $0.729 \pm 0.032$ & $0.22 \pm 0.08$ \\
\hline RLH & $8.00 \pm 0.79$ & $4.28 \pm 0.51$ & $4.90 \pm 0.41$ & $0.555 \pm 0.066$ & $0.726 \pm 0.041$ & $0.26 \pm 0.07$ \\
\hline $\mathrm{NC}$ & $8.50 \pm 0.90$ & $4.32 \pm 0.59$ & $5.00 \pm 0.42$ & $0.586 \pm 0.053$ & $0.726 \pm 0.041$ & $0.20 \pm 0.04$ \\
\hline STA & $9.20 \pm 0.92$ & $4.88 \pm 0.63$ & $4.70 \pm 0.45$ & $0.575 \pm 0.061$ & $0.765 \pm 0.027$ & $0.26 \pm 0.06$ \\
\hline MNM & $8.20 \pm 0.90$ & $4.54 \pm 0.51$ & $5.00 \pm 0.45$ & $0.647 \pm 0.055$ & $0.752 \pm 0.029$ & $0.15 \pm 0.05$ \\
\hline TSIG & $10.30 \pm 0.99$ & $5.53 \pm 0.42$ & $6.40 \pm 0.48$ & $0.873 \pm 0.014$ & $0.807 \pm 0.019$ & $-0.09 \pm 0.03$ \\
\hline TUV & $10.10 \pm 1.16$ & $5.74 \pm 0.58$ & $6.30 \pm 0.52$ & $0.977 \pm 0.017$ & $0.808 \pm 0.020$ & $-0.22 \pm 0.04$ \\
\hline BUB & $10.00 \pm 1.13$ & $5.11 \pm 0.69$ & $6.30 \pm 0.76$ & $0.798 \pm 0.023$ & $0.774 \pm 0.026$ & $-0.04 \pm 0.04$ \\
\hline ZBL & $8.90 \pm 0.77$ & $5.32 \pm 0.53$ & $6.00 \pm 0.45$ & $0.891 \pm 0.018$ & $0.794 \pm 0.021$ & $-0.13 \pm 0.03$ \\
\hline ROM & $9.80 \pm 1.04$ & $5.27 \pm 0.81$ & $5.20 \pm 0.57$ & $0.651 \pm 0.050$ & $0.758 \pm 0.043$ & $0.13 \pm 0.06$ \\
\hline SVM & $8.00 \pm 0.75$ & $4.95 \pm 0.44$ & $5.20 \pm 0.42$ & $0.651 \pm 0.060$ & $0.782 \pm 0.020$ & $0.17 \pm 0.07$ \\
\hline Mean & $8.99 \pm 0.20$ & $4.96 \pm 0.13$ & $5.50 \pm 0.59$ & $0.616 \pm 0.015$ & $0.756 \pm 0.007$ & $0.20 \pm 0.02$ \\
\hline $\begin{array}{l}\text { heterozyg } \\
\text { breeds. }\end{array}$ & 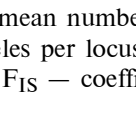 & 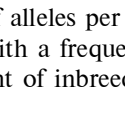 & - & 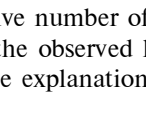 & 1 & $\begin{array}{l}\text { ne number } \\
\text { the expect } \\
\text { for the she }\end{array}$ \\
\hline
\end{tabular}

The observed heterozygosity in 21 of 25 studied breeds varied from $0.489 \pm 0.095$ in TUV to $0.651 \pm 0.050$ in ROM and $0.651 \pm 0.060$ in SVM. In four breeds (BUB, TSIG, ZBL, TUV), heterozygosity was significantly higher, such as from $0.798 \pm 0.023$ in BUB to $0.977 \pm 0.017$ in TUV. A comparison of the observed and expected heterozygosity revealed a significant deficit of heterozygotes in 21 of 25 studied breeds which was from $10.5 \%$ (ROM) to 24.9 and $25.1 \%$ (in KAR and SAL, respectively). The deficit of heterozygotes was confirmed by the positive values of the coefficient of inbreeding $F_{\text {IS }}$, which ranged from 0.13 in ROM to 0.36 in KAR and SAL. A slight (2.5 to $16.8 \%$ ) excess of heterozygotes was detected in BUB, TSIG, ZBL and TUV. The F $F_{\text {IS }}$ values for these four breeds ranged from -0.04 to -0.22 .

The analysis of molecular variance (AMOVA) showed that $5.02 \%$ of the genetic variability of breeds accounted for the differences between breeds and $94.98 \%$ - for the intrabreed component.

The genetic relationship between the studied breeds based on the $\mathrm{F}_{\mathrm{ST}}$ index is presented in Figure 1 as the PCoA plot. The lowest values of the index were observed for the following pairs: GRZ-STA $\left(\mathrm{F}_{\mathrm{ST}}=0.013\right)$, MNM-SVM $\left(\mathrm{F}_{\mathrm{ST}}=0.014\right)$, STA-SVM $\left(\mathrm{F}_{\mathrm{ST}}=0.014\right)$, ZBL-SVM $\left(\mathrm{F}_{\mathrm{ST}}=0.014\right)$, and the highest for KUL-EDL $\left(\mathrm{F}_{\mathrm{ST}}=0.071\right)$ and ALT-ROM $\left(\mathrm{F}_{\mathrm{ST}}=0,070\right)$ pairs. 


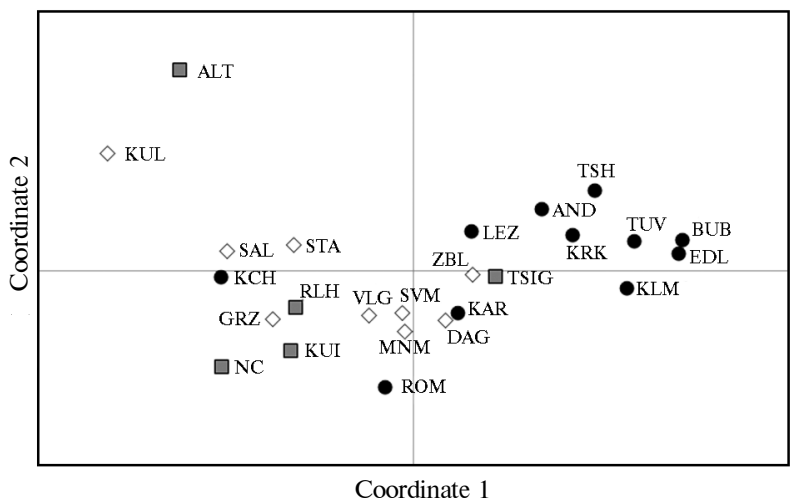

Fig. 1. Genetic differentiation of 25 Russian breeds of sheep (Ovis aries), belonging to different classes according to the wool and productivity types, in the space of the first two principal coordinates, calculated by the $\mathrm{F}_{\mathrm{ST}}$ index based on PCoA in paired comparison for 11 microsatellite loci: $\bullet-$ coarsewool, $\square-$ semifine-fleece, $\diamond-$ fine-fleece sheep breeds. See Table 1 for the explanation of the abbreviations for the sheep breeds.

sistent with our findings: the FST values between
According to D.L. Hartl and A.G. Clark [31], the F $_{\text {ST }}$ values $<0.05$ indicate a negligible genetic differentiation, 0.05 to 0.15 - a moderate, and 0.15 to 0.25 - a significant genetic differentiation. Most of the studied Russian breeds were characterized by negligible to moderate genetic differentiation. It is noteworthy that KUL and ALT breeds were at some genetic distance from most others. This was confirmed by $\mathrm{F}_{\mathrm{ST}}=0.05$. M.Yu. Ozerov et al. [25] found that the $\mathrm{F}_{\mathrm{ST}}$ values between Russian semifine-fleece sheep breeds averaged to 0.03 . In general, this is conpairs were 0.026 and 0.031 , respectively, and only for a $\mathrm{NC}$-KUI pair this value was lower $\left(\mathrm{F}_{\mathrm{ST}}=0.015\right)$.

The analysis of genetic distances [29] showed the greatest remoteness of KCH-BUB, ROM-TUV, KCH-TUV, ALT-ROM and KUL-TUV breeds, for which the $D_{N}$ values were $0.490,0.457,0.448,0.431$ and 0.430 , respectively. This could be due to the geographical remoteness of breeding regions, which prevented the exchange of genetic material. The minimum genetic distances were detected mainly between breeds belonging to the same productivity type: GRZ-STA $\left(D_{N}=0.087\right)$, MNM-SVM $\left(D_{N}=0.099\right)$, STA-SVM $\left(D_{N}=0.102\right)$. In general, it can be concluded that the genetic relationships between the studied breeds, assessed by the $\mathrm{D}_{\mathrm{N}}$ and $\mathrm{F}_{\mathrm{ST}}$ parameters were similar.

The phylogenetic tree (Fig. 2) built on the basis of the genetic distances $\left(D_{N}\right)$ demonstrated marked independent branches formed by Kuchugur and Romanov breeds, which probably was the result of their genetic uniqueness. The remaining breeds formed two clusters, the first of which was presented exclusively with fine-fleece and semifine-fleece breeds, and the second - with all coarsewool breeds as well as Tsigai and Transbaikalian fine-fleece breeds.

Four subclusters were distinguished in the first cluster, each of which included several breeds. Thus, a general subcluster (1-1) was formed by finefleeced breeds, such as Grozny, Stavropol, Manych merino and Soviet merino, which could be explained by one productivity type, breeding habitat, and the long-term (over 25 years) use of the gene pool of Australian merino sheep for their improvement [32]. Semifine-fleece breeds, such as Kuibyshev, North Caucasian mutton-wool and Russian long-haired, formed a separate subcluster (1-2). It is known that rams of the Romney Marsh breed originated in England were used to improve the first two breeds [33, 34], while Lincoln sheep were involved in deriving the Russian long-haired breed (at the initial stage) and North Caucasian mutton-wool breed (at the final stage of breed development) [35]. Combining breeds of the Mutton-Wool productivity type (Dagestan Mountain and Volgograd) in a separate cluster (1-3) could be due to the use of local inbred coarse-wool fat-rumped and fat-tailed sheep (as a maternal base) at the initial stage of their breeding, and Caucasian and Grozny merino breeds at the final 
stage [36]. The fourth subcluster (1-4) included Salskaya, Kulunda and Altay Mountain semifine-fleece breeds.

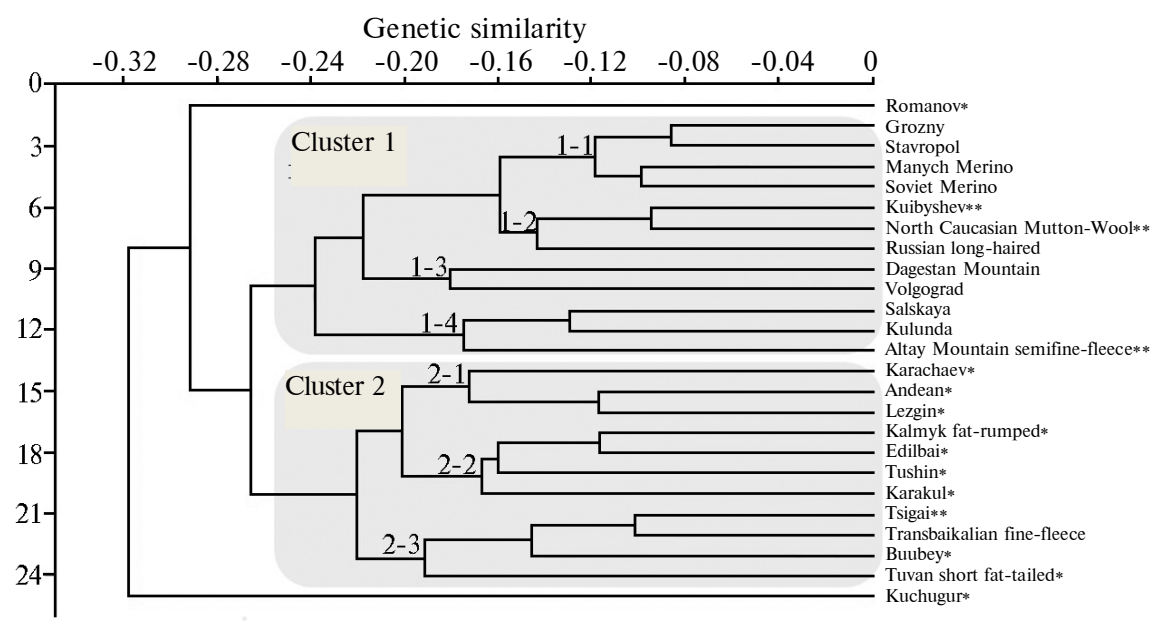

Fig. 2. The phylogenetic tree built based on the matrix of pairwise genetic distances between the studied Russian breeds of sheep (Ovis aries) by M. Nei [29]: 1-1, 1-2, 1-3 и 1-4 - subclusters of the cluster $1 ; 2-1,2-2$ and 2-3 - subclusters of the cluster 2 . One asterisk denotes coarse-wool, and two asterisks - semifine-fleece breeds; all the remaining are fine-fleece breeds. The UMPGA method was used to construct a dendrogram.

Three subclusters stood out in the cluster 2. The first one (2-1) was formed by sheep of Karachaev, Andean and Lezgin breeds developed in different mountainous areas of the North Caucasus through the long-term sustained selection of local coarse-wool sheep by local inhabitants. A distinctive feature of these breeds is an equally weighted ratio of meat, wool and dairy productivities, as well as an exceptional adaptability to keeping on the mountainous and lowland pastures [37, 38], which apparently determined their genetic proximity.

The second subcluster (2-2) included Edilbai, Kalmyk fat-rumped, Tushin and Karakul breeds, characterized by increased deposits of fat in the tail area. The first two breeds are of meat-fat productivity type, well adapted to grazing over large distances in semi-deserts and deserts, and have the fat tail. Furthermore, it is known that Edilbai breed was the improver at the initial stage of Kalmyk breed development [36]. The Tushin and Karakul breeds belong to fattailed sheep by the morphological classification, and also tend to fat deposition. Given the zoological classification, the productivity type, the area of spreading, the history of breeding and phenotypic similarity of breeds, an isolation of the two subclusters within the second cluster can be considered reasonable.

The third subcluster included Tsigai, Transbaikalian fine-fleece, Buubey and Tuvan short fat-tailed breeds of different productivity types and historical origins. The presence of the Transbaikalian fine-fleece, Buubey and Tuvan breeds in one subcluster is possibly due to the fact that indigenous coarse-wool Buryat-Mongolian sheep are found in their genealogy. Thus, Buubey breed was developed through a long-term improvement of indigenous Buryat sheep, Transbaikalian fine-fleece breed - through a long transformation of inbred coarse-wool Buryat-Mongolian sheep using the gene pool of the North Caucasian fine-fleece breeds [39]. Previously, the genetic similarity of the Tuvan indigenous breed of sheep, raised by the local tribes in the Republic of Tuva, and the Mongolian sheep has been already pointed out [40]. The explanation for the clustering of these breeds may be in the fact that all of them were derived and are still being raised in the extreme climatic conditions of Transbaikalia and Western Siberia. Probably, adaptive mechanisms, developed over hundreds 
of years, affected many loci, including microsatellite ones, and led to the similarity of the genetic profile. However, this assumption requires further investigation and validation.

Therefore, our findings give the most complete presentation of the state of the allele pool and genetic diversity of the majority of sheep breeds, the most commonly spread in Russia. In general, polymorphism in 11 microsatellite loci was quite informative for the differentiation sheep belonging to different breeds, while the nature of the identified relationships were mainly due to the wool type, productivity type and a breeding region. For a more profound research of the population structure and additional information on the genetic diversity at the genomic level, the investigation of Russian sheep breeds is anticipated with the application of DNA microarrays based on the multiple SNP markers.

\section{REFEREN CES}

1. Crispim B., Se no L., Egito A., Vargas Junior F., Grisolia A. Application of microsatellite markers for breeding and genetic conservation of herds of Pantaneiro sheep. Electronic Journal of Biotechnology, 2014, 17: 317-321 (doi: 10.1016/j.ejbt.2014.09.007).

2. Stolpovski i Yu.A. Concept and principles of genetic monitoring for the purpose of preservation in situ of domestic animals kinds. Agricultural Biology, 2010, 6: 3-8. Available http://www.agrobiology.ru/6-2010stolpovskiy-eng.html. No date (in Engl.).

3. Tautz D., Renz M. Simple sequences are ubiquitous repetitive components of eukaryotic genomes. Nucl. Acids Res., 1984, 12: 4127-4138.

4. Li t t M., Lut y J.M. A hypervariable microsatellite revealed by in vitro amplification of a dinucleotide repeat within the cardiac muscle actin gene. Am. J. Hum. Genet., 1989, 44: 397-401.

5. Put ma n A.I., $\mathrm{C}$ a r b o $\mathrm{ne}$ I. Challenges in analysis and interpretation of microsatellite data for population genetic studies. Ecology and Evolution, 2014, 4(22): 4399-4428 (doi: 10.1002/ece3.1305).

6. Dalvit C., S a c a E., Cassandro M., Gervaso M., Pastore E., Piasentie $r$ E. Genetic diversity and variability in Alpine sheep breeds. Small Ruminant Res., 2008, 80: 45-51 (doi: 10.1016/j.smallrumres.2008.09.005).

7. Kusza S., Di mov D., N agy I., B õs z e Z., Jávor A., Kuk ovi cs S. Microsatellite analysis to estimate genetic relationships among five bulgarian sheep breeds. Genet. Mol. Biol., 2010, 33(1): 51-56 (doi: 10.1590/S1415-47572010005000003).

8. Ferrando A., Goyache F., Parés P.-M., Carriyn C., Miry J., Jordana J. Genetic relationships between six eastern Pyrenean sheep breeds assessed using microsatellites. Spanish Journal of Agricultural Research, 2014, 12(4): 1029-1037 (doi: 10.5424/sjar/2014124-6173).

9. Y $\mathrm{Y} 1 \mathrm{maz}$ O. Power of different microsatellite panels for paternity analysis in sheep. Animal Science Papers and Reports, 2016, 34(2): 155-164.

10. Baumung R., Cubric-Curik V., Schwend K., Achmann R., Sölkner J. Genetic characterization and breed assignment in Austrian sheep breeds using microsatellite marker information. J. Anim. Breed. Genet., 2006, 123: 265-271 (doi: 10.1111/j.14390388.2006.00583.x).

11. Tapio I., Tapio M., Grislis Z., Holm L-E., Jeppsson S., Kantanen J., Miceikiene I., Olsake r I., Viinalass H., Eythorsdottir E. Unfolding of population structure in Baltic sheep breeds using microsatellite analysis. Heredity, 2005, 94: 448-456 (doi: 10.1038/sj.hdy.6800640).

12. N e ub a u e r V., Vogl C., S e reg i J., Sá fár L., B re m G. Genetic diversity and population structure of Zackel sheep and other Hungarian sheep breeds. Archives Animal Breeding, 2015, 58: 343-350 (doi: 10.5194/aab-58-343-2015).

13. Pariset L., Savarese M.C., Cappuccio I., Valentini A. Use of microsatellites for genetic variation and inbreeding analysis in Sarda sheep flocks of central Italy. J. Anim. Breed. Genet., 2003, 120(6): 425-432 (doi: 10.1046/j.0931-2668.2003.00411.x).

14. Kijas J.W., Lenstra J.A., Hayes B., B oitard S., Porto Neto L.R., S a n Cristobal M., Servin B., McCulloch R., Whan V., Gietzen K., Paiva S., Barendse W., Ciani E., Raadsma H., McEwan J., Dalrymple B. Genome wide analysis of the world's sheep breeds reveals high levels of historic mixture and strong recent selection. PLoS ONE, 2012, 10: e1001258 (doi: 10.1371/journal.pbio.1001258).

15. He at on M.P., Le y m a st e $\mathrm{r}$ K.A., K a lb fle is ch T.S., Kijas J.W., C 1 a rke S.M., McEwan J., Maddox J.F., Basnayake V., Petrik D.T., Simpson B., Smith T.P.L., $\mathrm{C}$ h it k o-M c K o w n C.G., the International Sheep Genomics Consortium. SNPs for parentage testing and traceability in globally diverse breeds of sheep. PLoS ONE, 2014, 9(4): e94851 
(doi: 10.1371/journal.pone.0094851).

16. Clarke S.M., He n ry H.M., Dodds K.G., Jowett T.W.D., Manley T.R., An d e r s o n R.M., M c E w a n J.C. A high throughput single nucleotide polymorphism multiplex assay for parentage assignment in New Zealand sheep. PLoS ONE, 2014, 9(4): e93392 (doi: 10.1371/journal.pone.0093392).

17. De niskova T.E., S e rmyag in A.A., B agi rov V.A., Okhlopkov I.M., G lad y r E.A., I va nov R.V., B re m G., Z i novi e va N.A. Comparative analysis of the effectiveness of STR and SNP markers for intraspecific and interspecific differentiation of the genus Ovis. Russian Journal of Genetics, 2016, 52(1): 79-84 (doi: 10.1134/S1022795416010026).

18. Elshire R.J., Glaubitz J.C., Sun Q., Poland J.A., Kawa moto K., Buckle r E.S., Mitche 11 S.E. A Robust, simple genotyping-by-sequencing (GBS) approach for high diversity species. PLoS ONE, 2011, 6(5): e19379 (doi: 10.1371/journal.pone.0019379).

19. E r n s t L.K., Z i n o v'e v a N.A. Biologicheskie problemy zhivotnovodstva $v$ XXI veke [Biological aspects of animal husbandry in the XXI century]. Moscow, 2008 (in Russ.).

20. A m e rk h a nov Kh.A. Ovtsevodstvo $i$ kozovodstvo Rossiiskoi Federatsii $v$ tsifrakh [Goats and sheep breeding in Russia: statistics]. Stavropol', 2015 (in Russ.).

21. Gladyr' E.A., Zinov'eva N.A., Burylova S.S., S e lionova M.I., Mo is e i k in a L.G., Ernst L.K., B re m G. Dostizheniya nauki i tekhniki APK, 2012, 11: $34-37$ (in Russ.).

22. Zinovieva N.A., S elionova M.I., Gladyr E.A., Petrovic M.P., Caro Pe trovic V., Ruzic Muslic D., Pet rovic M.M. Investigation of gene pool and genealogical links between sheep breeds of southern Russia by blood groups and DNA microsatellites. Genetika, 2015, 47(2): 395-404 (doi: 10.2298/GENSR1502395Z).

23. De niskova T.E., Kaneva L.A., Gladyr' E.A., S e lionova M.I., Zinov'eva N.A. Dostizheniya nauki i tekhniki APK, 2016, 30(8): 75-78 (in Russ.).

24. Tapio M., Ozerov M., Tapio I., Kantanen J., Toro M.A., Marzanov N., Ćinkulov M., Goncharenko G., Kiselyova T., Murawski M. Microsatellitebased genetic diversity and population structure of domestic sheep in northern Eurasia. BMC Genetics, 2010, 11: 76 (doi: 10.1186/1471-2156-11-76).

25. Ozerov M.Yu., Tapio M., Kantanen Yu., Marzanova S.N., Buzerov V.V., Andryukhin A.P., Shar lapa ev B.N., P et rov S.N., Marzanov N.S. Problemy biologii produktivnykh zhivotnykh, 2013, 3: 16-24 (in Russ.).

26. Zinov'eva N.A., Popov A.N., Ernst L.K., Marzanov N.S., Bochkare v V.V., S t re k o z o v N.I., B r e m G. Metodicheskie rekomendatsii po ispol'zovaniyu metoda polimeraznoi tsepnoi reaktsii $v$ zhivotnovodstve [PCR analysis in animal husbandry - guidelines]. Dubrovitsy, 1998 (in Russ.).

27. Peakall R., S mouse P.E. GenAlEx 6.5: genetic analysis in Excel. Population genetic software for teaching and research-an update. Bioinformatics, 2012, 28(19): 2537-2539 (doi: 10.1093/bioinformatics/bts460).

28. W e i r B.S., C o c k e r h a m C.C. Estimating F-Statistics for the analysis of population structure. Evolution, 1984, 38(6): 1358-1370 (doi: 10.2307/2408641).

29. N e i M. Genetic distance between populations. Am. Nat., 1972, 106(949): 283-292 (doi: 10.1086/282771).

30. H a m m e r O., H a r pe r D.A.T., R y a n P.D. PAST: Paleontological statistics software package for education and data analysis. Palaeontologia Electronica, 2001, 4(1): 4-9.

31. H a r 1 D.L., C 1 a r k A.G. Principles of population genetics. Sunderland, United Kingdom, 1997.

32. M o r o z V.A. Ovtsy, kozy, sherstyanoe delo, 2015, 2: 45-48 (in Russ.).

33. S e l'k i n I.I., S o k ol o v A.N. Ovtsy, kozy, sherstyanoe delo, 2002, 3: 10-12 (in Russ.).

34. M e dved e v M.V., E rok hi n A.I. Ovtsy, kozy, sherstyanoe delo, 2004, 1: 29-30 (in Russ.).

35. S e l'kin I.I. Severokavkazskaya myasosherstnaya poroda [A dual-purpose North Caucasian meat and wool sheep breed]. Stavropol, 2007 (in Russ.).

36. Erok hin A.I., K ot a rev V.I., Erok hin S.A. Ovtsevodstvo [Sheep breeding]. Voronezh, 2014 (in Russ.).

37. G a d z h i e v Z.K. Grubosherstnye ovtsy Dagestana [Dagestan coarse-wool sheep]. Makhachkala, 2010 (in Russ.).

38. M u r z i n T.V., Vershinin a V.A. Informatsionnyi byulleten', 2016, 1(11): 35-41 (in Russ.).

39. B i $1 \mathrm{t} \mathrm{u}$ e v S.I. Materialy Mezhdunarodnoi nauchno-prakticheskoi konferentsii "Znachenie i perspektivy razvitiya ovtsevodstva $v$ Agrarnoi ekonomike Sibiri $i$ Dal'nego Vostoka» [Proc. Int. Conf. «The value and prospects of sheep farming in the economy of Siberia and the Far East»]. Chita, 2016: 52-57 (in Russ.).

40. Stolpovski i Yu.A., Shimi it L.V., Kol N.V., Evsyukov A.N., Rusina M.N., Churgui -o ol O.I., Suli mova G.E. Analysis of genetic variability and phylogenetic relations in populations of Tuvinian short-fat-tailed sheep with ISSR-markers usage. Sel'skokhozyaistvennaya biologiya [Agricultural Biology], 2009, 6: 34-43 (in Russ.). 